\title{
Implementation of Open JPTP Fulfillment Policy to Improve Leadership Competence the Area of Gorontalo Government (Case Study of Open Selection 2016)
}

\author{
Harson Gasim, Arifin Tahir, Sarson W. Dj. Pomalato, Rauf A. Hatu \\ Postgraduate Program State University of Gorontalo
}

\begin{abstract}
The research aims to describe and analyze strategies and factors determining a successful implementation of open JPTP fulfillment policy to improve leadership competence in the area of Gorontalo Government.

The research applied the qualitative method and the data collection techniques included observation, in-depth interview analysis, documentation study, and focus group discussion. Furthermore, data analysis technique used here was the interactive model analysis. The findings clarified that (1) A successful implementation of open JPTP fulfillment policy to improve leadership competence in the area of Gorontalo government was realized by conducting the planning, implementation, and monitoring strategies collaborated with a limited public debate and selected candidate performance assessment; (2) Factors determining a successful implementation of open JPTP fulfillment policy to improve leadership competence in the area of Gorontalo Government were the communication factor, implementing attitude factor, resource factor, bureaucracy structure factor, training factor, motivation factor, and Mololawalo culture factor.
\end{abstract}

Keywords: Implementation, Policy, Jabatan Pimpinan Tinggi Pratama (Pratama Main Leadership Position)

DOI: $10.7176 / \mathrm{PPAR} / 9-6-03$

Publication date:June $30^{\text {th }} 2019$

\section{INTRODUCTION}

Leadership competence is important and shall be seriously concerned, as the leadership competence aspect has been widely used as a basic determinant of official position, especially in the public sector or government organization. Therefore, each leader shall be competent and have competences in order to lead their employees effectively, such as 'leaders' personal effectiveness, leaders' interpersonal competencies, and leaders' competence in managing organization (Sedarmayanti, 2017:243).

Therefore, leadership competences are the ability to manage and consists of attention (vision), meaning (communication), trust (emotional glue), and self (commitment, willingness to take risk) (Bennis and Burt Nanus in Wijaya, 2017:2). A leader shall have three abilities/competences, i.e. individual competences, leadership competences (leadership mastery), and organizational competences (organizational mastery) (Peter F. Drucker in Matondang, 2008:19).

Leadership competence becomes very crucial, because people believe that it is one of the factors that determine an organization direction. Muhaimin, in Abar (1993:71) argues that an organization may achieve success once it has an effective leadership factor. One of the implemented attempt to improve leadership competence in the implementation of local government, the government of Gorontalo implemented an open JPTP (Jabatan Pimpinan Tinggi Pratama, Pratama High Leadership Position) fulfillment policy. The policy intends to ensure the selection of professional and competene parties according to the position competence standards, since the placement of state civil apparatuses in the position, or in terms of management: "the right man on the right place" has been abandoned.

The law regulating the open JPTP fulfillment is the Regulation of the Ministry of Administrative and Bureaucratic Reform of the Republic of Indonesia Number 13 of 2014 that is enforced by the Regulation of the Ministry of Administrative and Bureaucratic Reform Number 13 of 2014 on Procedures on Open Fulfillment of Pratama Main Leadership Position in the Area of Government Instances whose appendix clarifying, "The fulfillment of Pratama Main Leadership Position is openly and competitively conducted among the Civil Servants by concerning the competence requirements, qualifications, levels, education and trainings, position track records, integrity, and other position requirements based on the legislative requirements in either national or regency/city level in one province" (www.bkn.go.id, accessed on December $31^{\text {st }}, 2016$ at 12 p.m.).

Then, by the issuance of the Law Number 5 of 2014 on Civil Servants, Article 108 Paragraph (3) and (4) confirm, "The fulfillment of Pratama Main Leadership Position is openly and competitively conducted among the Civil Servants by concerning the competence requirements, qualifications, levels, education and trainings, position track records, integrity, and other position requirements based on the legislative requirements in either national or regency/city level in one province."

In accordance with the consideration of the Regulation of the Ministry of Administrative and Bureaucratic Reform Number 13 of 2014, each institution that will do the open JPTP fulfillment shall coordinate and obtain a 
recommendation from the National Civil Service Commission. The Commission involvement as the committee will open a public room to monitor the selection process while there are violations against the merit system mandated by the Commission Law.

The open Pratama Main Leadership Position fulfillment aims to choose apparatuses that are able to bring a good change and make their institutions able to give a positive contribution to all Indonesian people.

Additionally, such open fulfillment is aimed to avoid any political issue in it. Therefore, it shall be performed fairly, objectively, transparently, accountably, and competitively against the practices of Corruption, Collusion, and Nepotism, making a good government that suits public expectation. Other main considerations in the open JPTP fulfillment are integrity and morality.

\section{LITERARY STUDY}

\section{Leader and Leadership}

Stoner and Wankel (1986:445) believe that "nevertheless, leadership abilities and skill in directing are important factors in managing effectiveness". Therefore, "a leader shall have three distinguished features in his/her moral, knowledge, and physic unless s/he is unable to influence his/her fellows or employees" (Thoha, 2005:141).

Fairchild (1966:174) conveys, "Leaders are those that lead by initiating social behaviors by regulating, directing, organizing, or controlling other attempts/efforts or by their power and position.

Additionally, Allee (1983:214) declares that "leader ... a guide, a conductor, a commander". Bennis and Townsend (1998:71) add, "Leaders are those that orient to the material result most, and the result certainty will be positive if the ones can identify what they want." Kouzes (2004:17) defines leaders as pioneers, those that are willing to step into an unknown situation.

Furthermore, Tead (1985:20) describes, "Leadership is the activity of influencing people to cooperate toward some goal which comes to find desirable." Beside personality integrity, the desirable leadership includes responsiveness towards public interest and problems, problem-solving ability, and correctly decision-making ability" (Surjadi, 2012:101).

Fred (1967:8) explains that "leadership is an ability to persuade or direct men without use of the prestige or power of formal office or external circumstance". Moreover, Freeman and Taylor (1950:4, 2012:13) mention that "leadership is the ability to create group action toward an organizational objective with maximum effectiveness and cooperation from each individual".

Stogdill (1950), in Feldman and Arnold (1983:288) propose that "leadership is a process of influencing the activities of an organized group in its task of goal setting a goal achievement".

Haiman (2003:5) declared that "leadership is an effort on his put direct the behavior of others toward a particular end".

\section{Leadership Competence}

Boulter et al., in Ambar (2009:11) reveal that competence is "a basic characteristic of an individual that enables $\mathrm{him} /$ her to produce a superior performance in his/her work".

Spencer and Spencer, in Moeheriono (2014:5) say that competence is "a basic characteristic of a person that is related to his/her performance effectiveness in his/her work, or a basic characteristic that connects to the causal relationship as the cause and effect of the criteria regarded as a reference or criteria that are effective, prime, or superior in the worksite or in a certain situation.

Amstrong and Baron (1998:297) state that competence is classified into three levels that are (1) Core competence, competence that shall be completely mastered by all people in an organization, (2) Generic competence, competence that shall be mastered by all people with the same occupation, and (3) Role-specific competence, competence targeted for a unique, specific, or special role and task that must be conducted. There is also another argument mentioning managerial competence (Wibowo, 2013:271-272).

In addition to that, Abdussamad (2014:49) suggests that "competence is a concept that defines individual knowledge, skill, and capability required for a successful task or work implementation”.

Dragadinis and Mentzas (2006:51-64) suggest the definition of competence as the following, "A competence can be defined as a specific, identifiable, definable, measurable knowledge, skill, ability, and/or other deployment related characteristic (e.g. attitude, behavior, physical ability) which a human resource may process and which is necessary for, or material to, the performance of an activity within a specific business context."

Becker, Huselid, and Ulrich (2001:156) argue that "competence refers to an individual's knowledge, skill, abilities, or personality characteristic that directly influence his or her job performance".

\section{State Civil Apparatus Position}

The Law Number 5 of 2014 on State Civil Apparatus Article 1 Number 1 clarifies that "State Civil Apparatus, hereinafter briefly referred to as $A S N$ is a profession for the State Civil apparatus and the government officers with work agreement that work in the government institutions" (the Law Number 5 of 2014 Article 1 Number 1). Furthermore, Article 1 Paragraph 2 confirms ASN Officers are civil servant officers and the government officers with work agreement promoted by the advisor for staff development and handed a job in a governmental position, 
or any other state jobs and given salary by according to the legislation.

Nainggolan (1983:101) believes that a position is "a job that shows the task, responsibility, authority, and right of a Civil Servant in an organizational unit. A position is a group of tasks and responsibilities given to an authorized official to a person in full time or time as the answer conveying stuffs to do, not the person".

In relation to the ASN Position, there is no exact definition of such in the Law Number 5 of 2014 on Civil Servants. However, Article 13 declares that "ASN position consists of: (a) Administration Position, (b) Functional Position, and (c) High Leadership Position" (Yustisia, 2016:5).

Besides, Article 19 the Law of State Civil Apparatus defines that "Chief Governing Position consists of: (a) main high leadership position, (b) intermediate high leadership position, and (c) pratama high leadership position".

\section{Open Fulfillment of Pratama High Leadership Position}

Substitution of High Leadership Position selected through an open selection is described in Article 116 Paragraph (1) and (2) the Law of State Civil Apparatus, "(1) Advisor for staff development is prohibited to substitute the High Leadership Position for two years started from the appointment of High Leadership Position, except $\mathrm{h} / \mathrm{she}$ violates the legislation and no longer fulfills the consideration of the Position, and (2) Substitution of the main and intermediate before two years can be conducted after the agreement of the President has been given" (Yustisia, 2016:66).

Requirements of the Pratama High Leadership Position are:

a. Have the lowest education qualification of bachelor degree or diploma IV,

b. Being equipped by Technical Competence, Managerial Competence, and Socio-cultural Competence in accordance with the standard competence of the Position,

c. Have the Position experience in the field related the selected Position at least five years (cumulative),

d. Currently or have had a position as an administrator or associate functional position for at least two years,

e. Have good track records on the Position, integrity, and morality,

f. No more than 56 years old, and

g. Physically and spiritually healthy (Article 107 Paragraph (3) President Regulation Number 11 of 2017).

5. Strategies of the Implementation of JTP Fulfillment Policy

Learned, Christensen, Andrews, and Guth, in Salusu (2000:90) defines strategy as "a pattern of goal, intention, target, general policy, and plants to achieve them". Meanwhile, Bintoro and Mustopadidjaja, in Bratakusumah (2004:68) describes a similar argument explaining strategy as the whole policy with an exact consideration to achieve a goal or solve a problem.

Hunger and Wheelen (2003:16) mentions that an organizational strategy constitutes a comprehensive formulae of planning on how a company will achieve their mission and goal. By the means of strategy, competitive features will be optimized; while competitive restriction will be minimized.

McKinsey, in Pearce (2008:428) indicates six components to ensure a successful strategy implementation, i.e. structure, system, joint value (culture), skill, style, and staff. Anthony and Govindarajan (2005:10) add that strategy may be implemented through an organization structure, human resource management, and culture. Organization structure stipulates the role, reporting relationship, and responsibility division to make a decision in an organization.

Furthermore, Anthony and Govindarajan (2005:7) propose that system is a certain, repetitive method to do an activity or a group of activities. It has a characteristic as a series of rhythmic, coordinated, and repeated steps. Kadji (2008:63) says that a system is basically a unit consisting of a number of components that are connected and interact to each other to achieve a goal.

6. Planning of the Implementation of Open JPTP Fulfillment Policy

Jones (1991:151) states, "Planning is the process of selecting and developing the best course to accomplish an objective."

Stoner and Freeman (1986:23) suggest that planning has certainly become one of our closest activities, even sometimes we do the activity as the implementer. In terms of management aspect, planning is frequently analyzed by applying the management process model.

In addition to that, Tery (1975:73) argues that "planning is both selecting and linking facts and making and using assumptions related to the future by describing and formulating certain activities necessary to achieve an objective".

Moreover, Robins (2013:1) believes that "the planning function encompasses defining an organization's goals, establishing an overall strategy for achieving these goals, and developing a comprehensive hierarchy of plans to integrate and coordinate activities".

\section{Implementation of Open JPT Fulfillment Policy}

Marshall (1992:48), in Mayang (2017:115) clarifies, "Organizing is the process of establishing formal relationships among people and resources in order to reach specific goals and objectives. The process is based on five organizing principles: unity of command, span of control, delegation of authority, homogeneous assignment, and flexibility. The organizing process involves five steps: determining the tasks to be accomplished, subdividing major tasks into individual activities, assigning specific activities to individuals, providing necessary resources, 
and designing the organizational relationships needed."

Additionally, Terry (1975:298) confirms, "Organizing is the establishing of effective behavioral relationship among persons so that they may work together efficiently and gain personal satisfaction in going selected task under given environmental condition for the purpose of achieving some goal or objectives."

Gouillart and Kelly, in Wasistiono (2003:85) conveys the 4R model for an organization transformation, namely (1) Reframing corporate direction, (2) Restructuring the company, (3) Revitalizing the enterprise, and (4) Renewing people.

\section{Supervision of Open JPT Fulfillment Policy}

Tery (2009:395) declares "supervision as a determinant of what has been implemented, evaluating the work achievement or if it is necessary, implementing corrective actions, so that the work output matches the plan".

Dale, in Winardi (2000:224) defines that "supervision is not only looking into a particular thing carefully and reporting the result, but also fixing and correcting it to achieve the planned objective".

Besides, Saefullah and Erni (2005:12) describe "the functions of supervision that are (1) evaluating the goal and target success as well as achievement according to the stipulated indicators, (2) taking a clarification and correction step over the violation that may be found, and (3) performing various alternative solutions over problems related to the goal achievement".

Fayol, in Harahao (2001:10) explains that supervision is an attempt to examine whether or not all stages have been implemented based on the stipulated plan, mandated instruction, and believed principle. It is intended to identify any weakness and error in order to prevent the event to happen.

\section{Policy Implementation}

Implementation of public policy, according to Tahir (2014:52), is "one of the activities in the public policy process. It often contradicts what is expected and becomes one of the policy products. It underlies the importance of deep understanding about the public policy study for the public policy implementation".

Furthermore, Kadji (2015:46) mentions that "the public policy implementation is one of the dimensions of public policy process that also determines whether the policy is integrated to the public importance. In this matter, we may emphasize that the stage of policy implementation or formulation may be well conducted. However, if during the implementation stage we do not concern the Standard Operating Procedures (SOP), what is expected from the policy product?"

To create an effective policy implementation, we need an implementation management. Nugroho (2003:163) and Tahir (2014:58-59) propose that management of implementation activity may be subsequently arranged through these stages: (1) Pre-implementation/strategy implementation, (2) Organization, (3) Motivation and leadership, and (4) Controlling.

In addition to that, Edwards III made a model of public policy implementation, 'four critical factors' that constitute the variables of communication, resources, disposition or attitude, and bureaucratic structure. Interaction of the impact among those factors, either directly or indirectly is presented in Figure 1.

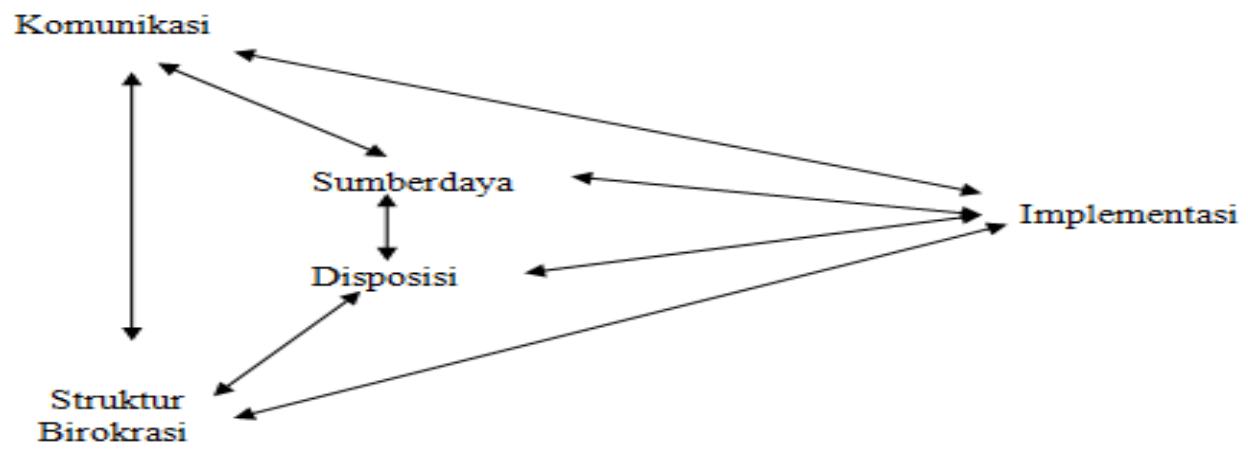

Figure 1

Factors Determining Policy Implementation by Edwards III

Source: George C. Edwards III (1980:148; Kadji, 2014:64; Tahir, 2015:61)

Edwards III (1980:10-11) states the description of Figure 1 as follows:

1. Communication: to produce an effective policy implementation, an implementer shall know what to do. The aim of the policy implementation shall be transmitted to members clearly, accurately, and consistently. When the decision-maker do not communicate well, it may create misunderstanding, preventing the policy to be well implemented because of information distortion.

2. Resource: even after a policy has been clearly and consistently communicated, when the resources are limited, it will not be effectively implemented. Therefore, it is necessary to have proper and professional (human) resources, relevant and adequate information on how a policy is implemented, and other facility resources; such as buildings, tools, land, and equipment. 
3. Disposition: the third approach considered important by Edwards. Disposition or good attitude of an implementer deeply affects an effective policy implementation as desired by the policy maker. When implementers do not do the policy as being expected by policy-makers, manipulation appears.

4. Bureaucratic structure: bureaucratic fragmentation may impede the bureaucratic organization structure. Meanwhile, one of the important sections of bureaucratic structure is the development of standard operating procedures (SOP) to maintain routine tasks and agreement of regulations that have been established.

\section{RESEARCH METHOD}

The research applied the qualitative approach. It "involved necessary efforts; such as proposing question and procedures, collecting specific data from participants, analyzing data inductively from specific to general themes, and interpreting the data" (Ahmad, 2015:52).

Research type implemented was the case-study method, as the research was restricted by time and activity. Additionally, the researchers gathered complete information by using various data collection procedures based on the determined time (Stake, 1995 in Creswell, 2015:20). Besides, the research demanded "an intensive, deep, detail, and comprehensive interpretation to one case" (Faisal, in Kadji, 2016:53).

Furthermore, the research data source was primary data collected by interviewing respondents and informants that were the Personnel Bureau of Gorontalo, Secretary of Selection Committee, and Selection Committee; while the secondary data were in forms of documents, reports, statistic data, and others that were related to the research focus.

Data collection techniques were: a) Observation, b) In-depth interview analysis, c) Documentation study, and d) Focus group discussion.

Moreover, data analysis technique used in the qualitative research was the interactive model analysis (Miles and Hubermen, 1992:15-19) whose process kept continuing, even before the data had been completely gathered. The analysis stages were as follows: (1) Data collection, (2) Data reduction, (3) Data presentation, and (4) Conclusion drawing.

\section{FINDINGS AND DISCUSSION}

\section{Strategy of the Implementation of Open JPTP Fulfillment Policy}

In an implementation of open JPTP fulfillment policy to improve leadership competence in the area of the government of Gorontalo, there were several strategies to do:

\section{Request of Indonesian Civil Service Commission Recommendation}

The government of Gorontalo proposed a request letter asking recommendation to the Indonesian Civil Service with the Number Letter: 800/BKPPD/04/XI/1976/2016 on October 13 ${ }^{\text {th }}, 2016$ on Recommendation Request. Due to the request, the Indonesian Civil Service Commission would give a recommendation with the Number Letter: B.2042/KASN/11/2016 on November $4^{\text {th }}, 2016$ on Request on JPTP Fulfillment Recommendation in Accordance with the New Regional Working Unit. In the letter, some stuffs should be included, i.e. (1) Indonesian Civil Service Commission instructed the Government of Gorontalo to start an open selection process according to the legislation, (2) Indonesian Civil Service Commission should concern the method as intended by the Circular Letter of the Minister of Administrative and Bureaucratic Reform of the Republic of Indonesia Number: B/3116/PANRB/2016 dated on September 20 ${ }^{\text {th }}$, 2016 on High Leadership Position Fulfillment in the Area of the Government of Gorontalo and related Regency/city Government related to the implementation of the Regulation of President Number 18 of 2016 on Regional Working Unit, (3) In the implementation of presentation and interview with the Selection Committee, Indonesian Civil Service Commission should monitor the implementation, (4) Immediately after the open selection process was done, the implementation result should be immediately reported to the head.

\section{Selection Committee Formation}

Selection Committee formation was stipulated by the Statement Letter of the Governor of Gorontalo Number 800/BKPPD/SK/04/XI/1079/2016 on Formation of Inaugural Selection Committee, Job Fit and Open Selection of High Leadership Position in the Area of the Government of Gorontalo.

Membership of Selection Committee consisted of: (1) Related officials from the Government institutions of Gorontalo, i.e. Regional Secretary of Gorontalo and Head of Regional Employment Board of Gorontalo, (2) Officials from other institutions related to the vacant position/task that was the head of National Civil Service Agency-XI Regional of Manado, and (3) Academicians/experts/professionals of State University of Gorontalo.

Tasks of Selection Committee, as mentioned by the Statement Letter of the Governor of Gorontalo Number 800/BKPPD/SK/04/XI/1079/2016 were as follows: (1) Performing an open JPTP selection in the area of the Government of Gorontalo, (2) Performing assessments and stipulating the result of open JPTP selection in the area of the Government of Gorontalo, (3) Performing assessment and competence test during an open JPTP selection in the area of the Government of Gorontalo in November 2016, and (4) Reporting the assessment result of open JPTP selection in the area of the Government of Gorontalo to the Governor of Gorontalo through an authorized official. 
In completing their tasks, selection committee was assisted by the competence assessor team and secretary of selection committee. Tasks of the secretary of selection committee were: (1) Preparing facilities and infrastructures for an open JPTP selection in the area of the Government of Gorontalo, (2) Preparing administration for the implementation of open JPTP selection activity in the area of the Government of Gorontalo, and (3) Assisting the selectiom committee to conduct their tasks.

\section{Job Vacancy Announcement}

A formal announcement of open JPTP fulfillment in the area of the Government of Gorontalo 2016 with the Number Announcement: 800/PANSEL/XII/6/2016 on Selection of Pratama High Leadership Official in the Area of the Government of Gorontalo. The announcement also mentions the application should be proposed on December $13-16^{\text {th }}, 2016$. Participants were only given four days to submit the application. Therefore, announcement issued by the head of selection committee had not been in accordance with the Regulation of the Minister of Administrative and Bureaucratic Reform of the Republic of Indonesia Number 13 of 2014 that was in accordance with the consideration that "Announcement is implemented for at least 15 work days before the due date of application acceptance".

\section{Administrative Selection}

Stipulation of administrative selection assessment result should be mentioned in the Decree of Selection Committee Head Number: 800/PANSEL/SK/XII/17/2016 on Stipulation of the Result of the open Selection Administrative Assessment of Pratama High Leadership Position in the Area of the Government of Indonesia. According to the Official Report of the Administrative Requirement File Verification Result of Pratama High Leadership Position in the Area of the Government of Gorontalo 2016, the file selection was done on Monday,

Supervising the implementation of open JPTP fulfillment policy was to prevent any violation possibility against the stipulated objective. Winardi (1998:78) argued that supervision was a systematic effort to determine a standard performance in planning to design an information feedback, to compare an actual performance and the determined standard, to determine whether a violation exists, and to take any necessary action to ensure that all organization resources have been effectively and efficiently used to achieve the goal.

\section{Factors Determining a Successful Implementation of Open JPTP Fulfillment Policy}

\section{a. Communication Factor}

Communication factor strongly determines an effective policy implementation. Research results in the field, several indicators as the successful determinant in communication on an open JPTP fulfillment policy implementation were:

\section{1) Communication Transmission}

According to the research findings, in the open JPTP fulfillment policy in the area of the government of Gorontalo 2016, the communication transmission was conducted based on the Governor Letter as the Advisor for Staff Development Number: 800/BPKD/04/XII/1077/2016 that was targeted for all leaders of Organisasi Perangkat Daerah in the area of the Government of Gorontalo to inform the policy to all civil servants in each working unit.

After that, the letter was forwarded to the regency/city government and vertical institutions in Gorontalo. It aimed to make the information of open JPTP fulfillment policy publicly accessible and provide more opportunities to state civil apparatuses in vertical institutions, in the Government of Gorontalo, and in the regency/city government to participate in the selection.

\section{2) Message Clarity}

The funding or the amount of the budget had not been put in details. Furthermore, instruments to assess either managerial or technical/field competence, methods to track track records, and some similar other stuffs had to be still formulated, making them compatible with the character or main functions of the selected position.

Therefore, factors of message clarity and policy implementation were important in a communication process. The clarity covered clarity of message content, aims that would be achieved, and dictions used in the whole communication of the activity process.

\section{3) Consistency}

Information consistency delivered in the implementation of open JPTP selection policy should be in accordance with the intention, aim, target, and substance of policy, and hence it gave certainty in the field. In addition to that, it might affect competences of both implementers and selection target/participant group to respond the accepted information.

Therefore, policy implementer should maintain communication consistency to prevent any confusion and misinformation and incorrect interpretation. In this context, consistency means that information announced by the selection committee and secretary of selection committee should be and had been suitable with the implementation. b. Disposition Factor or Implementer Attitude

For an effective policy implementation, implementers should not only know what to do, but also have to have commitment, openness, honesty, and understanding regarding the implementation. 


\section{1) Commitment of Implementation Apparatus}

Commitment in the implementation of open JPTP fulfillment policy in the increased leadership competence in the area of the Government of Gorontalo in 2016 was a condition in that implementation apparatuses, in this context, the selection committee was assisted by the secretary of selection committee to desire to maintain their involvement in the process of policy implementation.

Commitment held by the selection committee and secretary of selection committee to implement an open JPTP fulfillment was in accordance with the instruction of the Regulation of the Ministry of Administrative and Bureaucratic Reform of the Republic of Indonesia Number 13 of 2014. It mandated that open JPTP fulfillment should be conducted in a transparent, objective, and accountable way. By such commitment, the selection committee might implement the policy in accordance with the determined open selection goal.

We figured out that both selection committee and secretary of selection committee as well as other implementation apparatuses had implemented the open JPTP fulfillment policy in accordance with the existing law. They presented their commitment by their presence in each activity process and meetings discussing the decision-making.

\section{2) Understanding}

Data in the field clarified that members of selection committee and secretary team of selection committee still needed equal understanding of aspects related to administrative requirements, as there were applicants from certain functional positions of Widyaiswara whose application files were rejected, because the secretary team of selection committee considered that the administration requirement division did not mention civil servants that had been in a certain position. It indicated that policy implementers had not equal understanding of the policy.

\section{c. Resource Factors}

The intended resources were all resources that could be used to support a successful policy implementation as follows:

\section{1) Human Resources}

Human resources greatly influenced a successful policy implementation, since it was one of the important aspects related to an organization, institution, or industry. Werther and Davis, in Sutrisno (2009:1) confirmed that "human resources are a ready, capable, and prepared employees that want to achieve their organization goals".

According to the field data, the selection committee and secretary of selection committee as implementers of open JPTP fulfillment stipulated by the Governor Statement Letter had compatible qualification and competence with the selected JPTP. It could be proven by comparing the background of selection committee and the job description of JPTP that would be openly selected. Governor Statement Letter Number: 800/BKPPD/SK/04/XI/1079/2016 on Formation of the Selection Committee for Pengukuhan, Job Fit, and Open Selection of Pratama High Leadership Position in the Area of the Government of Gorontalo conveyed that there were five candidates with the qualification of two professors, two doctors, and one master. Meanwhile, the head of selection committee secretary had completed his doctoral program.

In an open JPTP fulfillment policy context, besides having education qualification and specification that were in accordance with the selected JPTP, members of selection committee and secretary team of selection committee should be civil servants with track records including good integrity, professionalism, and neutrality as well as achievement records. By such composition, they were expected to be able to choose suitable candidates and place them in suitable positions.

\section{2) Budget Resources}

Budget resources were important in the implementation to ensure the policy implementation, as without adequate supports, policy would not be effective to achieve goals and targets that had been determined.

Based on the field data, the number of vacant positions did not affect the amount of budget, declaring that the number of positions selected were given the same budget.

Besides, there was another activity that required a great amount of budget that was assessment. Therefore, for an effective and efficient budget use, civil servants that had participated in a selection or had participated in the same selection and wanted to participate in the same open selection in another institution or in the regency or province government, they did not necessarily have to the similar assessment.

\section{3) Facility and Infrastructure Resources}

Generally, facilities and infrastructures owned by the Regional Civil Agency Board for Education and Training of Gorontalo had supported the implementation of open JPTP fulfillment, but they still had to create some improved standards. For example, the Regional Civil Agency Board for Education and Training of Gorontalo should have a building equipped by facilities supporting the assessment center implementation; such as computers, electronic white board, interview room, discussion room equipped by monitoring devices in every room, and mobile server to implement competence test using the Computer Assisted Test (CAT) to provide more accurate, transparent, and accountable results.

\section{d. Bureaucratic Structure Factor}

Bureaucratic structures demanded in the implementation of open JPTP fulfillment policy to improve leadership 
competence in the area of the Government of Gorontalo were:

\section{1) Fragmentation or Responsibility Transmission}

Responsibility transmission should be done by policy implementers to complete their task by always helping and cooperating to each other. It was necessary to raise their spirit in achieving a successful policy implementation. Hasibuan (2009:70) defined responsibility as an obligation to implement all tasks/duties given to individuals due to authorities they accepted or had. Each authority would produce rights, responsibility, and duties to implement and account for.

\section{2) Authority}

Government of Gorontalo, as the institution holding an open JPTP implementation could implement the activity because of recommendations from the National Civil Service Commission. The recommendation mentioned authority provision to institutional holding an open JPTP fulfillment in accordance with the applicable law. Selection Committee obtained their authority through the Governor Statement Letter Number: 800/BKPPD/SK/04/XI/1079/2016 on Formation of Selection Committee for Open Selection. Referring to the Statement Letter, Selection Committee was given tasks, roles, and functions that came also with authorities and responsibilities.

\section{Prototype of Open JPTP Fulfillment Proposal}

Successful implementation of open JPTP fulfillment policy to enhance leadership competence in the area of the Government of Gorontalo was realized by several strategies that had been described above. However, to make the policy implementation more effective, the strategies should be collaborated with strategies to evaluate performances of selected candidates and limited public debates as explained here:

\section{a. Evaluation of Selected Candidate Performance}

Evaluation of selected candidate performance was necessary to investigate whether or not any breakthrough or innovation that had been offered by candidates during technical/field competence assessments was realized and if the innovation improve the organization performance.

The questions were that who had been given authorities to assess the selected candidate performance and when it could be performed. Fisher, Schoenfeldt, and Shaw (2005) mentioned that performance evaluation constituted a process in that employee contribution to their organization was assessed in a certain period. Therefore, Article 201 the Government Regulation Number 11 of 2017 on Civil Servant Management proposed, "Team assessing civil servant performances in a government institution was formed by authorized officials consisting of an authorized official, official managing the staff field, official that managing the internal supervision division, an related high leadership officials. According to the above legislation, civil servant performances should be assessed by a performance assessing team. However, as JPTP had an equal status to the performance assessing team's, only the authorized officials, in this context, the province secretary assisted by the selection committee and assessors that had performed assessments to the selected candidates are allowed to assess the candidate performances. Meggison (Mangkunegara, 2005:9) stated that performance evaluation/assessment was a process used by a leader to determine if employees had completed their tasks in accordance with their duties and responsibilities.

\section{b. Limited Public Debate}

Limited public debate activities were strategic to prevent officials whose policy and action were publicly unquestionable. In addition to that, pratama high leadership officials were more selected based on rational considerations, not on emotional and primordial relationships. They acknowledged public aspirations, democracy, leadership, credibility, morality, and wisdom that could be accounted for and hence they were able to select qualified officials.

Materials in the limited public debate were the issues related to the position task and function as well as the issues appearing in the community that were related to programs and policies related to the vacant position selected by the candidate.

In the limited public debate, commitment making officials might be well assisted in photographing competent candidates, in either their authority, competence, wisdom, or leadership ability. Both local and public knowledge was visible in the debate, as it would be assessed by the community themselves represented by local figures, public figures, religious figures, communities or mass organization, NGOs, academicians, practitioners, and representatives of several officers working in the organization where the vacant positions were offered.

Candidates should have good morals. For instance, they should not be involved in any corruption, collusion, and nepotism activity, did not violate any law, never told public lies, and held commitment to conduct the applicable law.

Additionally, besides the communication factor, implementer attitude/disposition, resources, and bureaucratic structure, there were still other factors that when integrated by the previous factors, they would determine the successful implementation of open JPTP fulfillment policy more.

a. Training

Basically, in the context of open JPTP fulfillment implementation, training was a learning activity or process to 
enhance implementer capabilities to understand goals, intentions, and scopes of the policy that would be implemented.

Training indicators were (1) knowledge, implementer capabilities to understand policies covering the goal, target, intention, and space that became the reason of making a certain decision or giving solution to a certain problem related to the policy implementation, (2) skill, implementer capabilities that were related to their knowledge of open selection policy goal, aim, and that could be implemented, and thus the determined goal and target could be well achieved, and (3) attitude, implementer behaviors during an interaction or communication with related stakeholders in a policy implementation. Kreitner (2010:160) argued that attitude was a tendency learned to consistently respond something related to a certain object either pleasantly or unpleasantly. In terms of policy implementation, attitude would encourage implementation apparatuses to have a big responsibility towards the result. Therefore, to achieve a successful policy implementation, they had to be certainly assisted by other parties, because it was impossible for them to do their duties all by themselves.

\section{b. Motivation}

Motivation came with some indicators, i.e. (1) individual perception, a process used by implementers to manage, interpret, and give meanings to policies. The process encouraged them to identify policies and all of the policy activities. A successful policy implementation was affected by implementer understanding and comprehension according to their sense acceptance, (2) necessity, implementer desire to show their roles in policy implementation activities that encouraged them to regulate various processes or actions to realize the concepts of implemented policy goal, target, and scope, and (3) expectation, a hope or belief expected to be true. Implementer suggestion in interpreting expectation might become an encouragement to develop or decline a policy implementation.

\section{c. Mololawalo Culture}

Mololawalo culture was "the whole thought of someone on an object that somehow underwent a meaning expansion, and hence included position. In receiving a profession as a job. There were several aspects to consider, i.e. (1) religion and (2) value believed by people" (D.K. Usman, interview held on March 21 $1^{\text {st }}, 2018$ ).

First, religion in the context of open selection policy was an attitude and behavior of an individual or target group rooted from the believed religious value. Mansyur Dali (interview held on March 20 ${ }^{\text {th }}, 2018$ ) believed that "in the context of Mololawalo culture and Gorontalo people, religion was from the Islamic teachings, as clarified by Prophet Muhammad, "We shall give this leadership to neither those who ask for it, nor those who are strongly eager to have it" ( $H r$. al-Bukhori Number 7149 and Muslim Number 1733). It confirmed that in the context of open position fulfillment, implementer or target group should be influenced and concerned of their religious views and values.

For "Gorontalo people, Islam had rooted, as conveyed by their slogan, 'Aadati Hulo-huloA to Syara'a, Syara'a Hulo-huloA to Kitabullah (Custom relies on sharia, sharia relies on the Book from God/Koran)'. The semboyan had always been the main foundation or all social aspects in Gorontalo" (Botutihe, 2006:xiii), including the aspects of open JPTP fulfillment, since basically, the policy was only an assessment method; while leader selection in the government organization should concern of the believed religious value held by people. Therefore, a leader should have attitudes and behaviors that were in accordance with God' commands and Islamic teachings as Gorontalo people knew as 'mo'oiyo to Allah, wo lo nabi mursalah lo wali u sagala (messenger of God, Prophet, and wali) (Botutihe, 2006:xiii).

Related to the implementation of open JPTP fulfillment policy, religion was closely connected to the declining number of individuals or state civil apparatuses that participated or enrolled in an open JPTP fulfillment selection. They regarded a position as a trust that most people were unable to accomplish well, except those that were blessed and guided by God. Trust obliged someone to choose an appropriate individual to hold the intended position.

Second, as an indicator, value was a belief held by implementers and target group that resulting in a positive behavior as an encouragement to implement activities related to the policy. Value directed implementer behavior and consideration, but not judged whether or not a certain behavior was right. Value was one of the most important parts in culture. A policy was considered as valid when it could be morally accepted by the value agreed and held by people where the policy was implemented.

In Gorontalo society, a leader could complete his/her duties well when "s/he at least had five aspects required in Gorontalo leadership, that were: (1) pure heart, (2) strong determination, (3) smart brain, (4) firm but loving behavior, and (5) polite speech (Botutihe, 2006:131).

In accordance with the explanation, the proposal of open JPTP fulfillment policy prototype to improve leadership competences in the area of Government of Gorontalo was: 


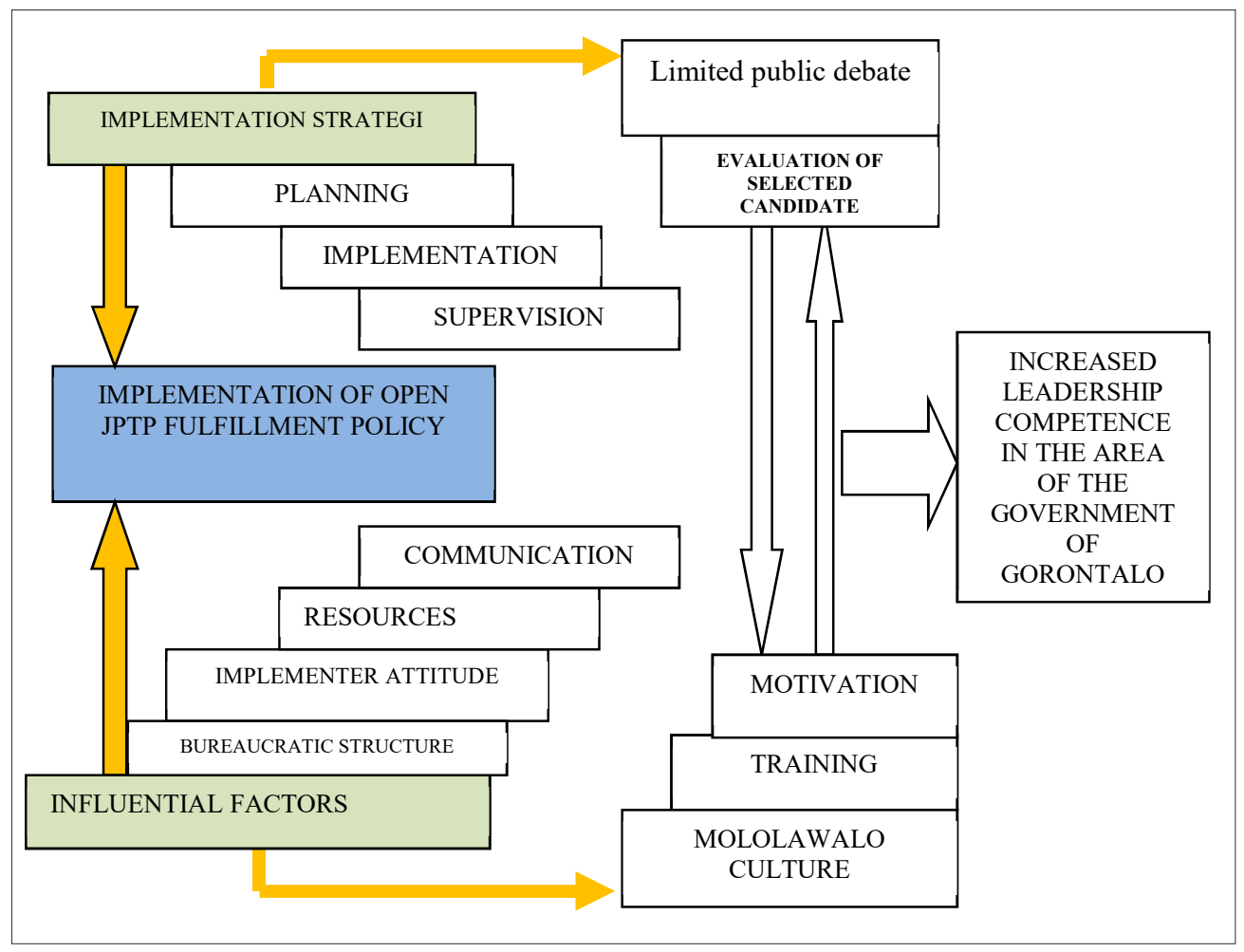

KESIMPULAN

Figure 2 Prototype of Open JPTP Fulfillment Policy Implementation Proposal

\section{CONCLUSION}

Referring to data and information collected during the research process, the conclusions were: first, in the implementation of open JPTP fulfillment policy to improve leadership competence, there were several strategies that should be conducted, namely request of State Civil Apparatus Commission recommendation, formation of selection committee, announcement of vacant positions, arrangement of administrative and competence selections, final interview, tracking (track records), stipulation of selection result, and supervision since the preparation and implementation stages. When collaborated to the strategy of limited public debate and assessment of selected candidate performance, those strategies would make a more effective policy goal achievement. Additionally, factors determining a successful implementation of open JPTP fulfillment policy were the communication factor with the indicators of communication transmitter, message clarity, and consistency; disposition or implementer attitude factor with the indicators of implementing apparatus commitment and understanding, factor of resources with the indicators of human beings, budget resources, and facility and infrastructure resources; and bureaucratic factor with the indicators of fragmentation or responsibility transmission and authorities.

Besides the above factors, we should concern if the training factor with the indicator of knowledge, skill, and attitude; motivation factor with the indicator of religion; and belief held by people.

\section{REFERENCES}

Abdussamad, Zuchri. 2014. Kompetensi Aparat dalam Pelayanan Publik. Yogyakarta: Deepublish.

Ahmad, Jamaluddin. 2015. Metode Penelitian Administrasi Publik Teori dan Aplikasi. Yogyakarta: Gava Media. Ambar, Teguh, Sulistiyani, Rosidah, 2009. Manajamen Sumber Daya Manusia. Yogyakarta: Graha Ilmu.

Anthony, Robert N., Vijay Govindarajan. 2005. Sistem Pengendalian Manajemen. Jakarta: Salemba Empat, $11^{\text {th }}$ ed.

Armstrong, Michael \& Baron, A. 1998. Performance Management: The New. Realities. Institute of Personnel and Development, New York.

Abar, Akhmad Zaini. 1993. Kritik Sosial, Pers, dan Politik Indonesia Dalam. Kritik Sosial dalam Wacana Pembangunan. Yogyakarta: UII Press.

Allee, John Gage. 1983. Webster's New Standar Dictionary. New York: Mc Loughlin Brothers Inc.

Warren and Robert Townsend. 1998. Reinventing Leadership: Menciptakan Kembali Kepemimpinan (translated) Batam: Inter Aksara.

Becker, Huselid, and Ulrich, D. (2001). The HR Scorecard: Linking People, Strategy, and Performance. Boston: Harvard Business School Press. 
Botutihe, Medi. 2006. Mo’odelo. Pustaka Gorontalo.

Bratakusumah, Deddy Supriady, and Riyadi. 2004. Perencanaan Pembangunan Daerah. Jakarta: PT. Gramedia Pustaka Utama.

Creswell, Jhon W. 2015. Research Design Qualitative, Quantitative, and Methods Approaches. Third Edition. CSAGE Publications. Thousand Oaks California 91320.

Draganidis, F. and Mentzas, G. 2006. Competency Based Management: A Review of System Approaches, Information Management \& Computer Security. Vol. 14. No.1. http://ns.hr-xml.org.

Edwards III George. 1980. Implementing Public Policy. Washington, D.C. Robert L. Peabody.

Fairchild, Henry Pratt. 1966. Dictionary of Sociology and Related Sciences. New Jersey: Littlefield Adam \& Co Paterson.

Feldman, Daniel C., and Arnold, Hugh J. 1983. Managing Individual and Group Behavior Organization. McGrawHill Book Co., Tokyo: Tosho Prenting CO, Ltd.

Fisher, Schoenfeldt, and Shaw. 2005. Human Resource Management. $6^{\text {th }}$ edition. Houghton Mifflin Co.

Fred E, Fiedler. 1967. Theory of Leadership Effectiveness. New York: Mo. GraHill.

Haiman, Franklyn S. 2003. Group Leadership and Democratic Action. Cambridge, Massachusetts: Houghton Mifflin.

Hunger, J. David and Wheelen, Thomas L. 2003. Manajemen Strategis. Yogyakarta: Andi.

Hasibuan, Malayu S.P. 2011. Manajemen Sumber Daya Manusia. Bumi Aksara, Jakarta.

Harahap, Sofyan, 2001. Sistem Pengawasan Manajemen. Penerbit Quantum, Jakarta.

Jones, Charles O. 1991. Pengantar Kebijakan Publik (Public Policy), translated by Ricky Ismanto. Jakarta: Penerbit CV. Rajawali.

Kouzes, James M., and Posner, Barry Z. 2004. Leadership the Challenge: Tantangan Kepemimpinan, translated by Wisnu Chandra Kristiaji. $3^{\text {rd }}$ ed. Jakarta: Erlangga.

Kreitner, Kinicki. 2010. Organizational Behavior. New York: McGraw-Hill

Kadji, Yulianto. 2015. Formulasi dan Implementasi Kebijakan Publik Kepemimpinan dan Perilaku Birokrasi Dalam Fakta Realitas. Gorontalo: UNG Press.

---------. 2008. Implementasi Kebijakan Publik Dalam Realitas. Cahaya Abadi. Tulungagung. 2016. Metode Penelitian Ilmu Sosial. Yogyakarta: Deepublish.

Matondang. 2008. Kepemimpinan: Budaya Organisasi dan Manajemen Strategik. $1^{\text {st }}$ ed. Yogyakarta: Graha Ilmu.

Miles, B. Mathew and Michael Huberman. 1992. Analisis Data Kualitatif Buku Sumber Tentang Metode-metode Baru. Jakarta: UIP.

Mangkunegara, Anwar Prabu. 2005. Sumber Daya Manusia Perusahaan. Remaja. Rosdakarya: Bandung.

Moeheriono. 2014. Pengukuran Kinerja Berbasis Kompetensi. Bogor: Ghalia

Nugroho, D, Riant. 2003. Kebijakan Publik Formulasi, Implementasi, dan Evaluasi. Jakarta: PT Elex Media Komputindo Kelompok Gramedia.

Mayang, Wiwik Widyawati. 2017. Implementasi Kebijakan Sistem E-procurement dalam Peningkatan Efektivitas Pengadaan Barang/jasa Pemerintah di Lingkungan Kementerian Agama Seprovinsi Gorontalo. Dissertation. Gorontalo:UNG.

Pearce and Robinson. 2008. Manajemen Strategis: Formulasi, Implementasi, dan Pengendalian. Jakarta: Salemba Empat.

Sedarmayanti. 2017. Perencanaan dan Pengembangan Sumber Daya Manusia untuk Meningkatkan Kompetensi, Kinerja, dan Produktivitas Kerja. Bandung: Refika Aditama.

Sutrisno, Edy. 2010. Manajemen Sumber Daya Manusia. Jakarta: Kencana. Prenada Media Group.

Saefullah and Ernie. 2005. Pengembangan Sumber Daya Manusia. Jakarta: Grasindo.

Salusu. 2000. Pengambilan Keputusan Stratejik. Jakarta: Gramedia.

Stoner, James AF. and Charles Wankel. 1986. Manajemen. $3^{\text {rd }}$ ed, vol. 2, translated by Wilhelmus W, Bakowatun. Intermedia, Jakarta.

Surjadi. 2012. Pengembangan Kinerja Pelayanan Publik. Bandung-Refika Aditama.

Robbins Stephen P. and Timothy A. Judge, 2013. Organizational Behavior $15^{\text {th }}$ ed. New Jersey: Pearson Education, Inc., publishing as Prentice Hall.

Thoha, Miftah. 2005. Perspektif Perilaku Birokrasi: Dimensi-dimensi Prima Ilmu Administrasi Negara. JakartaRajawali Press.

Tahir, Arifin. 2014. Kebijakan Publik dan Transparansi Penyelenggaraan Pemerintah Daerah. Bandung: Alpabeta. Terry, George R., 1975. Principles of Management. $6^{\text {th }}$ ed. Illinois: Richard D. Irwin. Homewood. 2009. Prinsip-prinsip Manajemen. PT. Bumi Aksara.

Tead, Ordway. 1985. The Art Leadership. McGraw-Hill Book Co., Inc., New York.

Yustisia. 2016. The Law Number 5 of 2014 on State Civil Apparatus and the Government Regulation on the Latest Employment. Jakarta: Visimedia.

Wijaya, Candra and Nasrul Syakur Chaniago. 2017. Perilaku Organisasi. Medan: Lembaga Peduli Pengembangan 
Pendidikan Indonesia (LPPPI).

Wibowo. 2013. Budaya Organisasi Sebuah Kebutuhan untuk Meningkatkan Kinerja Jangka Panjang. Jakarta: RajaGrafindo Persada.

Wasistiono, Sadu. 2003. Kapita Selekta Manajemen Pemerintah Daerah. Sumedang: Alqoprint.

Winardi, J. 2000. Manajemen Perilaku Organisasi, $1^{\text {st }}$ ed. Jakarta: Prenada Media. 